\title{
LACTOSE INTOLERANCE AND THE IMPORTANCE OF LACTOSE-FREE DAIRY PRODUCTS IN THIS CONDITION (Review)
}

\author{
Viorica Bulgaru *, ORCID: 0000-0002-1921-2009, \\ Liliana Popescu, ORCID: 0000-0003-3381-7511, \\ Rodica Siminiuc, ORCID: 0000-0003-4257-1840 \\ Technical University of Moldova, 168 Stefan cel Mare Blvd., Chisinau, Republic of Moldova \\ *Corresponding author: Bulgaru Viorica, viorica.bulgaru@tpa.utm.md
}

Received: 10. 11. 2021

Accepted: 11. 24. 2021

\begin{abstract}
The paper is a review of the importance of expanding the lactose-free dairy segment to give consumers the opportunity to consume milk and dairy products if they suffer from lactose intolerance. When there is a lactase deficiency in the body, in the small intestine lactose is not hydrolyzed, the volume increases and the fluidity of the intestinal contents increases, allowing lactose to reach the colon where it is fermented by colonic bacteria. Lactose intolerance is a condition that depending on the form developed will show different symptoms and consumers suffering from this disease may ingest amounts between 12-24 $\mathrm{g}$ of lactose consumed during a day, taking into account certain recommendations, compared to allergy to milk proteins, where the consumption of dairy products is prohibited. Due to the rich intake of important macro and micronutrients in human nutrition, dairy products cannot be missing from the daily diet. In this context, methods are proposed, in particular ultrafiltration, for obtain free lactose milk that does not affect its composition and properties. Consumers suffering from lactose intolerance should be properly informed about the lactose content in manufactured lactose-free dairy products. This can be done after using highperformance instrumental methods of analysis that can detect the lowest values of lactose content in dairy products.
\end{abstract}

Key words: free lactose milk, lactose, lactose intolerance, milk, milk allergy.

Rezumat. Lucrarea prezintă o trecere în revistă a importanței extinderii segmentului de lactate fără lactoză pentru a oferi consumatorilor posibilitatea de a consuma lapte și produse lactate chiar dacă suferă de intoleranță la lactoză. Atunci când există un deficit de lactază în organism, în intestinul subțire lactoza nu este hidrolizată, volumul creste si fluiditatea conținutului intestinal creste, permițând lactozei sa ajungă in colon unde este fermentata de bacteriile colonice. Intoleranța la lactoză este o afecțiune care, în funcție de forma dezvoltată, va prezenta simptome diferite. Consumatorii care suferă de această boală pot ingera cantități cuprinse între 12-24 g de lactoză consumate pe parcursul unei zile, ținând cont de anumite recomandări, spre deosebire de alergia la proteinele din lapte, unde este interzis consumul de produse lactate. Datorită aportului bogat de macro și micronutrienții importanți pentru alimentația umană, produsele lactate nu pot lipsi din alimentația zilnică. În acest context, 
sunt propuse metode, în special ultrafiltrarea, pentru obținerea laptelui fără lactoză. Consumatorii care suferă de intoleranță la lactoză ar trebui să fie informați în mod corespunzător cu privire la conținutul de lactoză din produsele lactate, fabricate fără lactoză. Acest lucru se poate face după utilizarea unor metode instrumentale de analiză performante care pot detecta valorile reale ale conținutului de lactoză din produsele lactate.

Cuvinte cheie: lapte fără lactoză, lactoză, intoleranță la lactoză, lapte, alergie la lapte.

\section{Lactose provinience}

Lactose is a naturally disaccharide of milk (Figure 1) (it is less contained in cow's milk compared to breast milk) [1, 2]. Is a disaccharide that must be cleaved by enzyme lactase, into glucose and galactose [3, 4].

The body then absorbs these simpler sugars into the bloodstream.

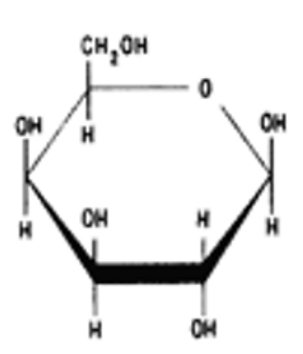

Galactose

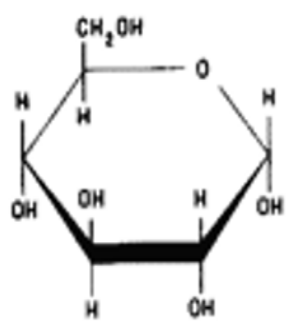

Glucose

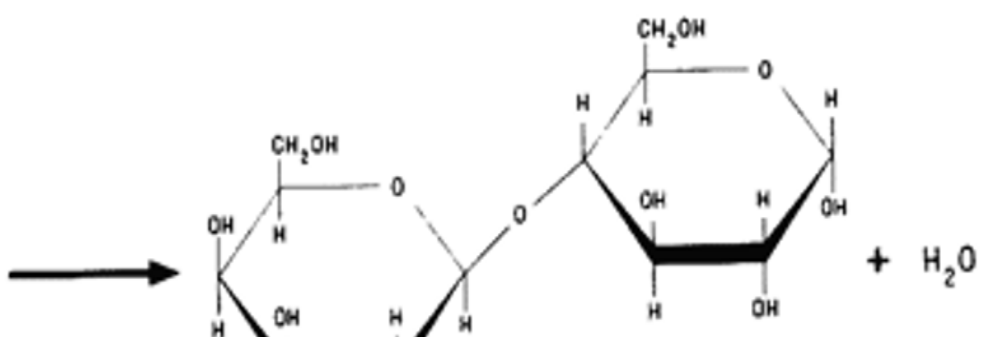

Lactose

Water

Figure 1. Lactose formation by a condensation reaction between glucose and galactose.

Lactose is an important component of the carbohydrates group important in the diet from an early age, due to the fact that it is a good source of energy [2, 5]. Studies by various scientists show that lactose promotes better absorption of calcium, magnesium, zinc, manganese and other minerals. Lactose promotes the development of beneficial bacteria in the intestinal tract and prevents the development of pathogenic ones [5].

\section{Intolerance to lactose}

Lactose intolerance is manifested in people whose body lacks lactase or is in small amounts. [6]. Lactase that is present in the intestinal epithelium breaks down lactose into glucose and galactose.

The symptoms of lactose intolerance (Figure 2) are specific to each individual, and their manifestation depends very much on the amount of lactose ingested and lactase reserves in the consumer's body. [7].

Lactase is located in the microvilli of the small intestine. When the lactase enzyme is deficient, the amount of unhydrolyzed lactose reaches the colon. Under the action of the microflora in the colon, lactose is fermented, and as a result a certain amount of lactic acid and hydrogen is formed, a process that leads to the formation of gases in the colon (Figure 3). Lactase deficiency is not always associated with lactose intolerance. Only about $50 \%$ of lactase activity is required for efficient digestion of lactose [1,9].

Lactose intolerance exists of several types, depending on the amount of lactase formed in the body and the severity of symptoms. 


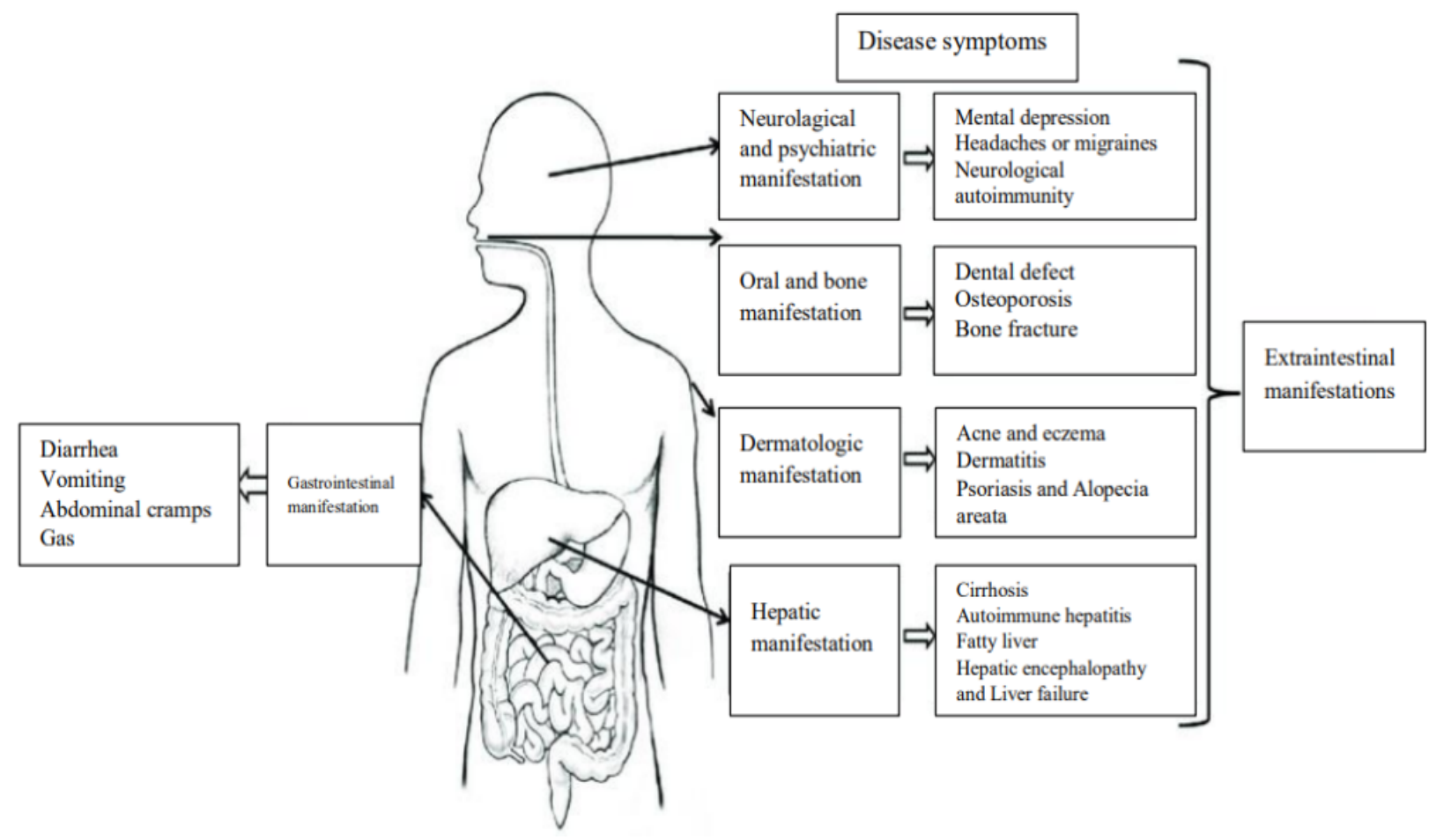

Figure 2. Manifestations of lactose intolerance, [8].

The primary lactase deficiency is specific to the partial or total lack of lactase that can develop in childhood at different ages, being a common cause of malabsorption or lactose intolerance. The primary lactase deficiency is recognized as: adult hypolactasia, lactase deficiency or hereditary lactase deficiency. Primary lactase deficiency manifests about $70 \%$ of the world's population.

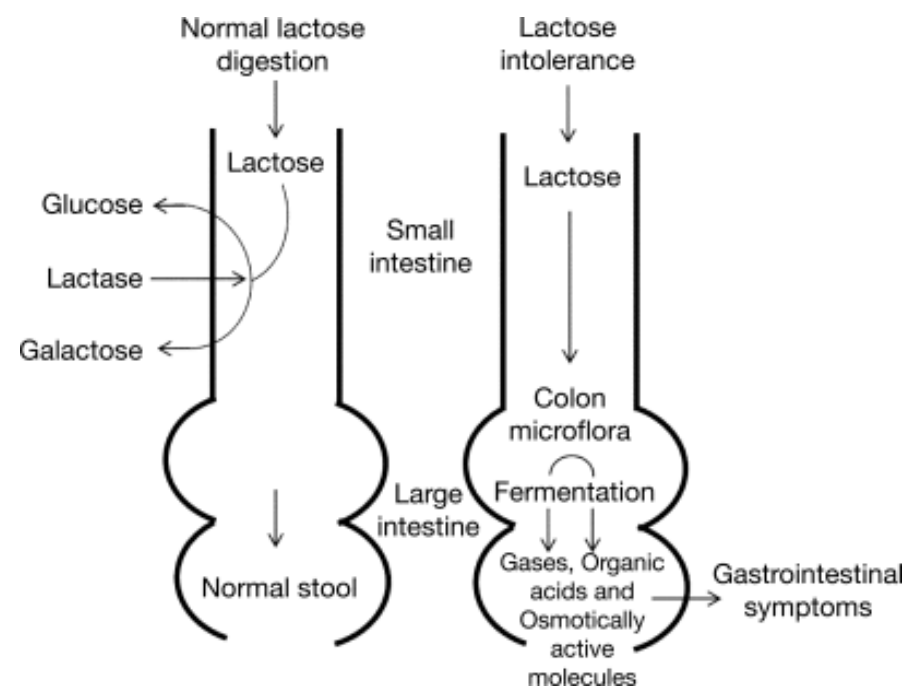

Figure 3. Lactose digestion in the colon [10].

Secondary lactase deficiency is the lactase deficiency that results from lesions of the small intestine (acute gastroenteritis, diarrhea) is defined as secondary deficiency, which can occur at any age even from the youngest.

Congenital lactase deficiency is very rare in patients. In this case lactose is practically absent from the small intestine.

Developing lactase deficiency manifests itself as a time-consuming condition, more often seen in premature babies, which usually disappears with the growth of children $[1,11]$. 
Lactose intolerance is a condition that is not dangerous to the health of the consumer $[9,12,13]$.

Milk is an indispensable food product in human nutrition, especially in children's nutrition, a hypothesis supported by EFSA. That is why recommending a lactose-free diet is a very delicate issue. In this context, in order to confirm the presence of this condition, it is recommended that patients take recognized lactose tolerance tests.

Research shows that consuming a maximum $12 \mathrm{~g}$ of lactose in the case of people with lactose intolerance results in no minor symptoms. Larger amounts of lactose can also be tolerated if they are properly distributed between meals.

Table 1

Domination of primary lactase deficiency, [11]

\section{Groups of people where the incidence of total or partial lactose deficiency is $60-100 \%$}

Examples: Arabs, Greek Cypriots, Thais, Indonesians, Chinese, Koreans, South Nigerians, Hausa, black Americans, Latinas, Eskimos, Canadian and American Indians, Chami Indians, etc.

Groups of people where the incidence of total or partial lactose deficiency is $\mathbf{2}-\mathbf{3 0 \%}$

Examples: Northern Europeans, Hima, Nomadic Fulani, individuals from Punjab and New Delhi, etc.

Among the European adult population, the incidence of lactose intolerance is between $4 \%$ and $56 \%$. The lowest rate (4-5\%) was recorded among the population of Northern Europe, (Table 1) [14].

\section{Lactose intolerance and milk protein allergy.}

Allergy is a disease of the immune system caused by some food / environmental agents, causing serious health problems to people.

The major food groups considered allergic are: peanuts, cow's milk, eggs, nuts, fish, shellfish, soy and wheat. In the case of cow's milk, the major allergic component is considered casein and alpha lactoalbumin and beta lactoblobulin. The symptoms of milk protein allergy can manifest immediately after ingesting the food or even after 72 hours, manifesting some of the following symptoms: hives, swelling, nausea and wheezing [12,14]. Lactose intolerance is related to milk sugar which is found naturally in milk.

The lack of a proper and correct process of hydrolysis of lactose in the small intestine leads to the appearance of symptoms specific to lactose intolerance, which in the case of a correct consultation cannot be associated with allergy to milk proteins.

People who show symptoms specific to allergy to milk components are advised to remove dairy products from the diet, while in case of lactose intolerance they are advised to keep under strict record the amount of lactose consumed in a single intake (during or at the end of the meal), which must not exceed $12 \mathrm{~g}$ of lactose.

People with lactose intolerance are allowed to consume dairy products where the amount of lactose has decreased due to the process of lactic fermentation that occurred in the manufacture of those products: yogurt, matured cheeses, fresh cheese, $[9,13,14]$. Unlike cow's milk protein allergy, lactose intolerance is not a disease. (Table 2). 
Lactose intolerance vis-a-vis an allergy to cow's milk protein, $[1,3,4,15,16]$

\begin{tabular}{|c|c|c|}
\hline Cause & Lactose Intolerance & $\begin{array}{l}\text { Allergy to cow's milk protein } \\
\text { (casein and whey protein) }\end{array}$ \\
\hline $\begin{array}{l}\text { Predominance } \\
\text { (EU) }\end{array}$ & Between 4-56 \% & $1 \%$ - in children, $0.5 \%$ in adults \\
\hline Symptoms & $\begin{array}{l}\text { Bloating, flatulence and abdominal } \\
\text { pain, diarrhea }\end{array}$ & $\begin{array}{l}\text { urticarial, vomits, acute } \\
\text { dermatitis and so on }\end{array}$ \\
\hline Diagnosis & $\begin{array}{l}\text { Lactose intolerance test, Hydrogen } \\
\text { breath test, Intestinal biopsies }\end{array}$ & $\begin{array}{l}\text { Skin prick and blood tests for } \\
\text { antibodies }\end{array}$ \\
\hline Prognosis & $\begin{array}{l}\text { It can evolve as temporary or } \\
\text { permanent. Most people with LI } \\
\text { tolerate small amounts of lactose. }\end{array}$ & $\begin{array}{l}50 \% \text { of cases progress and are } \\
\text { treated by the age of } 12 \text { months; } \\
90 \% \text { - up to the age of } 3 \text { years. }\end{array}$ \\
\hline Management & $\begin{array}{l}\text { Based on the type of lactose } \\
\text { intolerance, the amount of lactose } \\
\text { (milk and dairy products) that can } \\
\text { be consumed is determined. } \\
\text { Fermented dairy products can be } \\
\text { consumed by patients with lactose } \\
\text { intolerance. }\end{array}$ & $\begin{array}{l}\text { Milk or Dairy exclusion (medical } \\
\text { and nutritional supervision) }\end{array}$ \\
\hline
\end{tabular}

\section{Lactose present in milk and dairy products}

The production of lactose-free or low-lactose milk / dairy products has an upward trend, which makes it possible to consume dairy products among people suffering from lactose intolerance without showing any symptoms of this condition [17].

People with lactose intolerance can tolerate up to $12 \mathrm{~g}$ of lactose in a single serving [18]. The tolerance level of people with lactose intolerance actually appreciates the amount of lactose that can be consumed daily, however it is allowed to consume different dairy products in small quantities and correctly distributed per day [2, 14, 19, 20].

According to EFSA (European Food Safety Authority) yogurt is a product indicated in the diet of lactose intolerant people because the beneficial bacteria in yogurt (Lactobacillus delbrueckii susp. Bulgaricus and Streptococcus thermophiles) in amounts of $10^{8} \mathrm{cfu} / \mathrm{gram}$, improve lactose digestion [21]. Consumption of dairy products is very important for people, because it ensures the assimilation of macro and micronutrients essential to health, mainly calcium intake. For example, a $30 \mathrm{~g}$ serving of cheese or $250 \mathrm{~g}$ of yogurt or $250 \mathrm{ml}$ of milk contains about $300 \mathrm{mg}$ of calcium. The same amount of calcium can be covered by eating 3 $\mathrm{kg}$ of fruit or $750 \mathrm{~g}$ of vegetables, (Table 3) [22].

Preventive strategy to maintain good health regarding lactose intolerance includes:

- general hygiene conditions

- Hygiene in food and water

- Proper hand washing

- Diets (advices) (Table 4)

- Well-balanced diet

- Introduction of fiber in the diet 
Lactose Content of Common Foods [11, 23, 24, 25, 26, 27, 28, 29]

Dairy Products

Yogurt

Milk

Skim milk

Cream

Butter

Edam, Gauda cheese

Parmiggiano cheese

Cheddar

Cottage

Mozzarella

Cheese (goat)

Ice cream

Kefir

Condensed milk

Evaporated milk

Whey
Lactose Content, $\mathrm{g} / 100 \mathrm{~g}$

4

4

4,3-5,7

0,1

0,8

$>0,5$

$>0,4$

$0,09-0,5$

1,0-3,1

0,1-1,59

2,2

3,6-8,4

$\sim 4,0$

9,9-14,0

10-11

5,1

- Avoidance / exclusion of processed foods from the diet

- Choosing a low tempo for food consumption

- Beware of consuming products that cause allergies

- Drinking of lot of fluids (non-sugar based)

- Maintenance of healthy gut microbiota

- Introduction of probiotics and prebiotics in the daily diet

- Maintenance of hygiene rules

- Avoidance / exclusion of harmful substances that can reach the intestine

- Smoking

- Drugs which damages intestinal mucosa,

- Alcohol

- Preserving the integrity of the epithelium,

- Maintenance of enterocytes, [30].

Table 4

Foods allowed / prohibited in lactose intolerance, [1, 31]

Food - to be avoided

- Milk: whole, low-fat, nonfat, cream, powdered, condensed and evaporated

- Chocolate-containing milk

- Butter, cottage cheese, ice cream, creamy/cheesy sauces, cream cheeses, soft cheese and mozzarella

- Cream

- Milk, bread, crackers

- Muffin, waffle, pancake, biscuit

- Bakery products
Food - to be allowed

- Lactose-free milk, soy milk

- Lactose-free milk and dairy products, hard cheeses

- Yogurts containing live cultures

- Kefir

- Fruits

- Vegetables

- Legumes

- Cereals

- Meat, fish, eggs

- Vegetable fats 


\section{Development of lactose-free foods}

Given that nowadays the consumer is well informed about the food composition to be consumed and how it can influence his health, there is a rising demand for healthy products [32], even more serious in choosing the right foods are consumers suffering from any health conditions / diseases. Also today, people with lactose intolerance are offered a rich assortment of milk without lactose of nonlactic origin. Following a strict lactose-free diet can lead to serious immune or colon health problems [33], due to deficiencies in some macro or micronutrients. Of course, the easiest way to avoid lactose in the daily diet of a person suffering from lactose intolerance is to eliminate dairy products from the diet [34], but the patient must keep in mind that milk and dairy products are foods that come with a very important intake of nutrients for the consumer health, first of all being a rich source of calcium, (Table 5) [20].

Table 5

Calcium content in low lactose milk, [8]

\begin{tabular}{c|c}
\hline Sources & Calcium, ppm \\
\hline Soy milk & 3.90 \\
Rice milk & $1,5-1,6$ \\
Coconut milk & 9,40 \\
Lactose hidrolysed milk & $112,7-120$ \\
\hline
\end{tabular}

Dairy products, such as cheese, yogurt, can meet the calcium requirement of people with lactose intolerance [35] and at the same time keep the lactose intake within the recommended limit.

For these reasons the focus should be on expanding the range of lactose-free foods in the dairy group.

Dekker et al. (2019) emphasized that for all milk production, low-lactose products ensure market expansion by mobilizing groups of consumers who do not attended common dairy products [36].

The growth of the lactose-free dairy market is impressive, showing the fastest growth in the field. By 2022, an increase of $7.3 \%$ is expected compared to $2.3 \%$ we have today, reaching the figure of 9 billion euros, data extracted from a Euromonitor analysis (Figure 4) [37]. In the Republic of Moldova, no lactose-free dairy products are produced, these being provided only for import.

In the category of lactose-free milk and dairy products, the production and consumption of lactose-free milk comes first, followed by acidic dairy products, namely yogurt (Figure 4), [38].

At the industrial scale, several methods are used to break down lactose into raw milk, depending on the facilities and infrastructure of the factory.

The use of lactase ( $\beta$-galactosidase) for the breakdown of lactose is considered the basic method in the manufacture of lactose free dairy products.

$\beta$-galactosidase, the enzyme responsible for the hydrolysis of lactose, is widely used in the dairy industry for the hydrolysis of lactose in milk and whey. $\beta$-Galactosidase is an enzyme that can be found in plants, animal organs and microorganisms.

For the hydrolysis of milk lactose, yeast enzymes are usually used, which have an optimal neutral $\mathrm{pH}$, and for the hydrolysis of whey lactose, fungal galactosidases (Aspergillus sp.) With optimal acid $\mathrm{pH}$ are used [39 - 41]. 


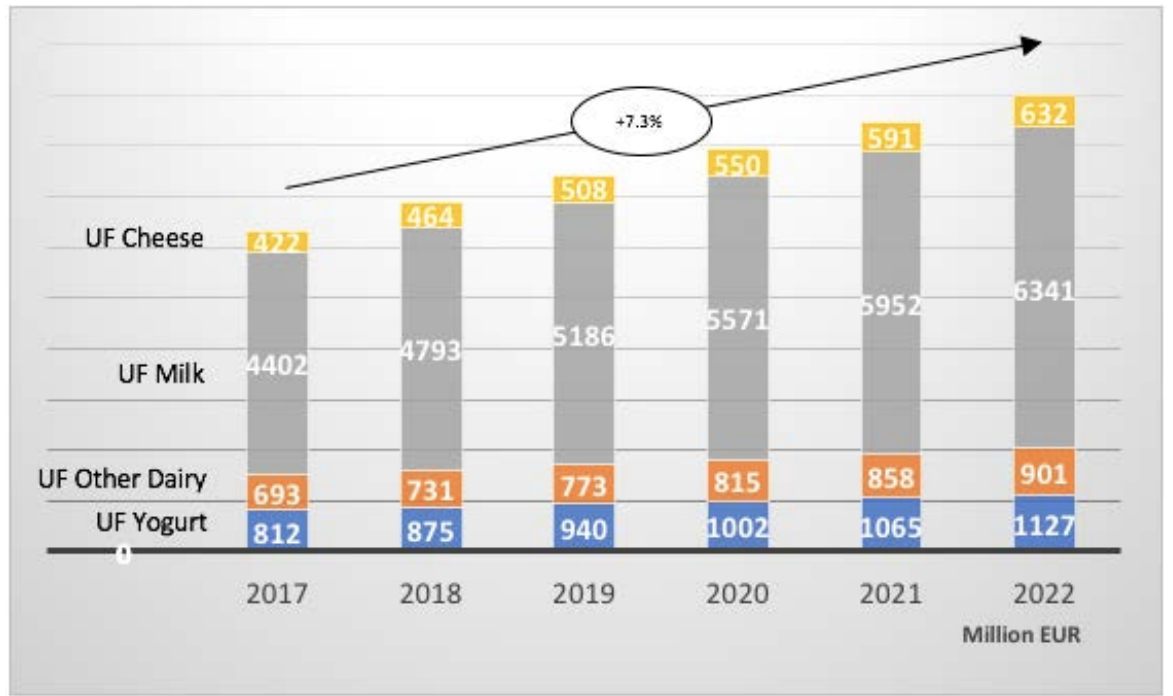

Figure 4. Growth rate of the lactose-free dairy market segment for the period 2017-2022 $[37,38]$.

At the industrial scale 2 methods are used: pre-hydrolysis or batch process and post hydrolysis or aseptic process.

The stages of the pre-hydrolysis process are:

a. introduction of neutral lactase into milk;

b. cooling the milk to $4-8{ }^{\circ} \mathrm{C}$ and maintaining it at this temperature throughout the process;

c. incubating the milk for 24 hours, with continuous stirring

d. classical pasteurization of milk;

e. classical homogenization of milk;

f. milk packaging.

Milk is heat treated, which reduces residual enzyme activity to a minimum which is an advantage of regulation and labeling in some countries [38].

Stages of the post-hydrolysis process are:

a. heat treatment of milk by UHT technique;

b. introduction of the sterile lactase into milk;

c. milk packaging;

Lactase hydrolysis occurs in the package, during the storage of milk at the enterprise, for 3 days at ambient temperature. This period is sufficient for lactose to be bound to monosaccharides. The milk is then distributed for sale [38].

The breakdown of the total amount of lactose in milk (approximately $4.8 \%$ ) into glucose and galactose can lead to a lactose-free product with a higher degree of sweetness (Table 6) and specific flavor compared to normal milk. These defects in the finished product are considered major challenges for operators in the lactose-free dairy industry, [42]. An alternative to avoid the appearance of sweet taste in milk is to use different filtration methods such as microfiltration, nanofiltration, ultrafiltration and reverse osmosis, through filtration membranes a part of lactose is separated, after which the classical process continues (Figure 5 ), or chromatography techniques (combined with the hydrolysis of the remaining lactose) are used $[43,44]$. 


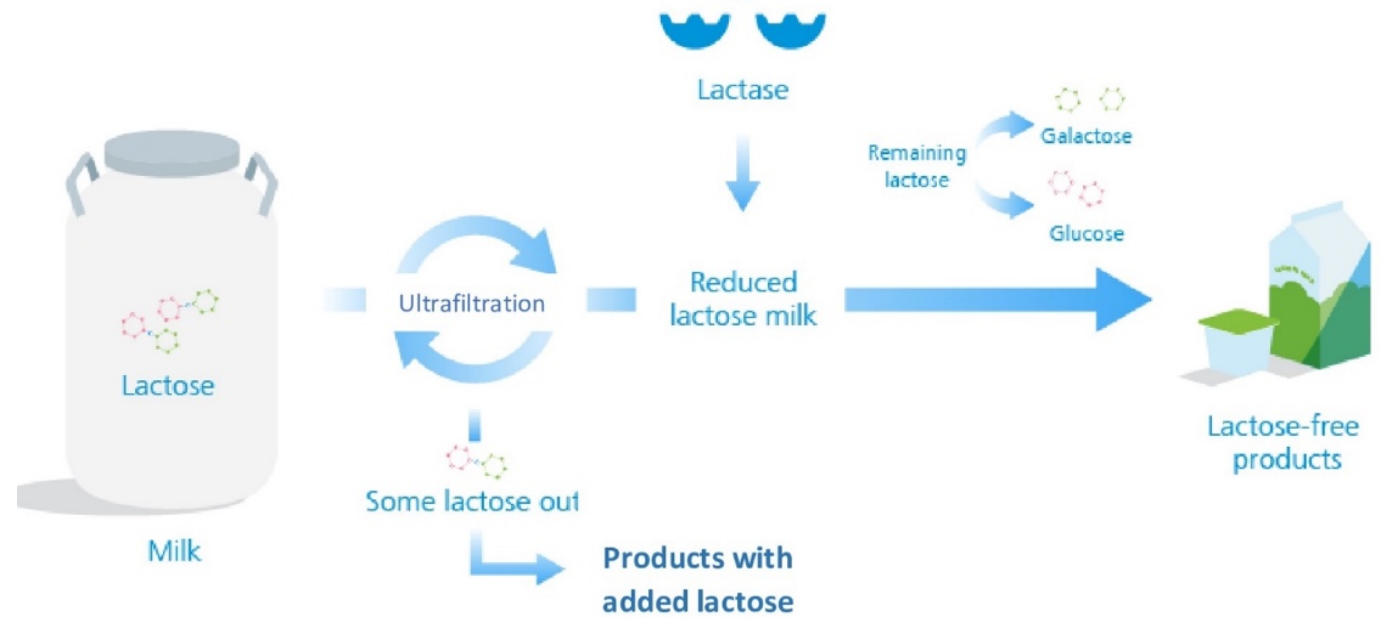

Figure 5. Production of lactose free products, [42].

Table 6

Comparative characteristics of lactose-free and whole milk [45]

\begin{tabular}{cccc}
\hline Characteristics & $\begin{array}{c}\text { Lactose-free milk } \\
\text { (ultrafiltration) }\end{array}$ & $\begin{array}{c}\text { Milk with a low lactose content } \\
\text { (lactose enzymatic hydrolysis) }\end{array}$ & Milk \\
\hline $\begin{array}{c}\text { Lactose } \\
\text { content }\end{array}$ & $<0,01 \%$ & $<1 \%$ & $4,8 \%$ \\
& & &
\end{tabular}

$\begin{array}{llll}\text { Taste } & \text { Natural taste } & \text { Sweet taste } & \text { Natural taste }\end{array}$

Carbohydrate $35 \%$ less carbs, $20 \%$ Identical content to natural content fewer calories milk Natural

The result is excellent quality milk that tastes almost identical to regular milk [6].

Carbohydrates have a great influence on the quality indices of dairy products [46] and in their category can be not only glucose and galactose resulting from the breakdown of lactose, could form significant amounts of lactulose, formed by isomerization of lactose at high temperatures. The amount of lactulose present in lactose-free milk is an important analytical indicator of the milk heat treatment it has undergone. Checking the severity of the heat treatment performed by analyzing the lactulose content allows to detect fraud and distinguish the type of heat treatment applied [47].

There are different types of lactose-free cheeses on the market [6]. Lactose from cheese is separated at different stages of the technological manufacturing process: whey separation and bacteria fermentation [48].

Lactose-free cheeses are made by incubating milk with lactase before the technological operations specific to the cheese-making process, a technique applied in particular to the manufacture of fresh cheeses, which have a higher whey content and are not fully matured and therefore in which could remain a higher lactose content without the use of lactase $[38,49]$.

While in matured cheeses the lactose content can be reduced to a minimum and without incubating the milk with lactose, because the manufacturing process of matured cheeses requires the elimination of a larger amount of whey from the cheese during ripening (30, 60, 180 days). lactic acid bacteria consume virtually all the lactose present in cheese. The 
more a cheese has been ripened, the less lactose remains in the final product; therefore, the concentration of lactose in hard (highly ripe) cheeses is low and can be easily tolerated by most people with primary lactose intolerance [6].

Yogurt is a fermented dairy product that has in its composition bacteria (L. delbrueckii subsp. Bulgaricus and S. thermophilus), introduced with the starter culture. Due to these bacteria that produce $\beta$-galactosidase in yogurt and produce lactose digestion in vivo, people with lactose intolerance can consume yogurt without having any symptoms of the given condition $[6,49]$.

Studies show that after fermentation of yogurt, a large amount of lactose remains in the product. When consuming yogurt, the microorganisms in yogurt, which contain intracellular $\beta$-galactosidase, retain their viability to the small intestine where they release $\beta$-galactosidase into the lumen [50], which participates in the hydrolysis of lactose.

However, several research results say that the capabilities of these microorganisms may vary in the process of digesting lactose [50, 51, 52, 53]. The European Food Safety Authority (EFSA) has examined human clinical trials evaluating the efficacy of yogurt in improving lactose digestion [21]. According to the expert group, there is sufficient evidence that there is a cause-and-effect association between yogurt consumption and improved lactose digestion when consuming yogurt with a microbial load of at least $10^{8} \mathrm{cfu} / \mathrm{gram}$ [21].

\section{Instrumental analysis of sugar content in lactose-free dairy products}

The correct choice of lactose-free dairy products by consumers suffering from lactose intolerance is guided by the correct labeling of these products. Declarations indicating the absence or reduced presence of lactose in food should be regulated under Regulation no. 1169/2011 (EU, European Union) [54], and minimum / maximum limits for lactose intolerance to lactose and galactosemia [14, 55].

To be labeled 'lactose-free', milk must contain $<0.01 \%(\mathrm{w} / \mathrm{w})$ lactose. Identifying the low amount of lactose is usually a very difficult process that can only be achieved by using sensitive and accurate methods. Until there is not a standardized method for determining the lactose content that allows the identification of low amounts of lactose in lactose-free dairy products [56]. According to the literature, there are innovative methods for quantifying lactose at low milk levels (Table 7).

Table 7

Sensitive and specific methods for the determination of residual lactose content

\begin{tabular}{|c|c|c|c|c|}
\hline $\begin{array}{c}\text { Instrumental } \\
\text { Analysis }\end{array}$ & Extraction Technique & $\begin{array}{l}\text { LOD-LOQ }\left(\mathrm{mg} \cdot \mathrm{L}^{-1}\right. \\
\left.\text { or } \mathrm{mg} \cdot \mathrm{kg}^{-1}\right)\end{array}$ & Products & Reference \\
\hline HPAEC-PAD & $\begin{array}{l}\text { Liquid extraction, } \\
\text { filtration, purification by } \\
\text { Thermo Scientific Dionex } \\
\text { OnGuard IIA, } 2.5 \mathrm{cc} \\
\text { cartridge }\end{array}$ & $\begin{array}{l}\text { MDL: } 0.5-30 \text { in } \\
\text { water }\end{array}$ & $\begin{array}{l}\text { whole milk, } \\
\text { lactose-free } \\
\text { milk, } \\
\text { yogurt, } \\
\text { lactose-free } \\
\text { cheese }\end{array}$ & [58] \\
\hline HPAEC-PAD & $\begin{array}{l}\text { Heated microwave } \\
\text { extraction by water, } \\
\text { sonication, filtration, } \\
\text { extraction, filtration, SPE } \\
\text { sulfonic acid bonding } \\
\text { column, filtration }\end{array}$ & $\begin{array}{c}\text { LOD: } 1.4-2.5 \text { LOQ: } \\
2.6-4.1\end{array}$ & hard cheese & [59] \\
\hline
\end{tabular}




\begin{tabular}{|c|c|c|c|c|}
\hline HPAEC-PAD & $\begin{array}{c}\text { Dilution, centrifugation, } \\
\text { ultrafiltration. }\end{array}$ & LOQ: 10 & $\begin{array}{l}\text { milk, yoghurt, } \\
\text { chocolate } \\
\text { drink, } \\
\text { whipped } \\
\text { cream, } \\
\text { vanilla } \\
\text { custard, } \\
\text { cream } \\
\text { cheese, } \\
\text { margarine, } \\
\text { firm cheese, } \\
\text { whipped } \\
\text { cream, } \\
\text { chocolate } \\
\text { hazelnut } \\
\text { cream }\end{array}$ & {$[62]$} \\
\hline HPAEC-ECD & $\begin{array}{c}\text { Incubation, clarification, } \\
\text { filtration }\end{array}$ & LOD: 100 & $\begin{array}{c}\text { milk, } \\
\text { fermented } \\
\text { milk and } \\
\text { lactose-free } \\
\text { milk products }\end{array}$ & {$[60]$} \\
\hline UHPLC-MS/MS & $\begin{array}{l}\text { Defatting, clarification, } \\
\text { dilution }\end{array}$ & $\begin{array}{l}\text { LOD: } 0.023-0.050 \\
\text { LOQ: } 0.123-0.157\end{array}$ & UHT milk & {$[61]$} \\
\hline HILIC-MS/MS & $\begin{array}{l}\text { Liquid extraction, } \\
\text { filtration }\end{array}$ & LOQ: 15 & $\begin{array}{l}\text { raw, whole, } \\
\text { semi- } \\
\text { skimmed and } \\
\text { skimmed } \\
\text { milk }\end{array}$ & [63] \\
\hline $\begin{array}{l}\text { LactoSensR } \\
\text { Amperometry } \\
\text { Method }\end{array}$ & $\begin{array}{l}\text { Homogenization, dilution, } \\
\text { biosensor assay kit }\end{array}$ & LOQ: $50-80$ & $\begin{array}{l}\text { low-lactose } \\
\text { and lactose- } \\
\text { free milk, } \\
\text { milk } \\
\text { products, } \\
\text { products } \\
\text { containing } \\
\text { dairy } \\
\text { ingredients }\end{array}$ & [64] \\
\hline $\begin{array}{l}\text { Lactulose Assay Kit } \\
\text { Enzymatic method }\end{array}$ & $\begin{array}{c}\text { Extraction, glucose } \\
\text { removal pre-treatment, } \\
\text { spectrophotometry at } 340 \\
\mathrm{~nm}\end{array}$ & $\begin{array}{l}\text { LOD } 0.79 \text { LOQ } \\
2.65 \text { for liquid } \\
\text { samples } \\
\text { LOD } 0.13 \\
\text { LOQ } 0.44 \\
\text { for solid or semi- } \\
\text { solid samples. }\end{array}$ & $\begin{array}{c}\text { low-lactose } \\
\text { and lactose- } \\
\text { free milk and } \\
\text { dairy } \\
\text { products }\end{array}$ & [65] \\
\hline $\begin{array}{l}\text { Freezing point } \\
\text { depression }\end{array}$ & - & - & $\begin{array}{l}\text { low-lactose } \\
\text { and lactose- } \\
\text { free milk }\end{array}$ & {$[56]$} \\
\hline
\end{tabular}

LOD: Limit of Detection, LOQ: Limit of Quantification, MDL: Method Detection Limit. 
Impressive limit of detections (LODs) were achieved with high-performance anionexchange chromatography with pulsed amperometric detection (HPAEC-PAD) [58, 59, 62], ultra-high performance chromatography coupled to tandem mass spectrometry (UHPLCMS/MS) [61], hydrophilic interaction liquid chromatography to tandem mass spectrometry (HILIC- MS/MS) [63]. Some enzymatic methods have undergone improved modifications to more accurately determine the amount of lactose and to reduce their interference with other lactose-free milk sugars [65]. Cryoscopy can also be used for this purpose, by measuring the decrease of the freezing point due to the enzymatic hydrolysis of lactose [56]. Biosensors are of interest for this purpose due to their high specificity and their ability to translate the detection of the analyte into an amperometric or potentiometric signal [64].

\section{Conclusions}

Lactose is an important component of milk in terms of nutritional and energy value, but for people suffering from lactose intolerance this component becomes problematic. Lactose intolerance is a globally widespread issue affecting a very high percent-age of the population, which greatly influences the habits of people with this condition. Lactose intolerance is not a disease but the symptoms are very acute and uncomfortable.

For these reasons, people suffering from lactose intolerance should have a special diet. In the context that dairy products cannot be excluded from the diet, being a category of foods indispensable in the diet of humans, even people with lactose intolerance, modern methods of obtaining lactose-free milk are implemented on an industrial scale. In the future, we expect to see many different new product launches in this rapidly expanding segment of the dairy industry.

The development of analytical methods based on innovative technologies is of major importance, they allow the correct quantification of lactose content in lactose-free milk, which allows the correct identification of the nutritional properties of lactose-free products and their correct labeling.

Acknowledgements: The research was funded by State Project 20.80009.5107.10, nr. PS-62 "Personalized nutrition and intelligent technologies for my well-being", running at Technical University of Moldova.

\section{References}

1. Morelli L. et al. Lactose Intolerance: Clinical Symptoms, Diagnosis and Treatment. In: Global Diabetes Open Access Journal, 2019, 1(1), 1-10.

2. Lomer M.C.E., Parkes, G.C. and Sanderson, J.D. Review article: lactose intolerance in clinical practice-myths and realities. In: Aliment Pharmacol Ther. 2008; 27(2), 93-103.

3. Mattar R., de Campos Mazo, D.F. and Carrilho, F.J. Lactose intolerance: diagnosis, genetic, and clinical factors. In: Clin Exp Gastroenterol, 2012, 5, 13-21.

4. Chen X.Y. et al. Lactose and lactose derived-oligosaccharides: More than prebiotics? In: International Dairy Journal, 2017, 67, 61-72.

5. Toward R.E., Walton G.E., Gibson G.R. Immunosenescence and the gut microbiota: The role of probiotics and prebiotics. In: Nutrition and Aging, 2012, 1, 167-180.

6. Facioni M. S., Raspini B., Pivari F., Dogliotti E., and Cena H. Nutritional management of lactose intolerance: the importance of diet and food labelling. In: Journal of Translational Medicine, 2020, 18(1), 260.

7. Tomar B.S. Lactose intolerance and other disaccharidase deficiency. In: Indian Journal of Pediatrics. 81, 2014, 876-880.

8. Suri S., et al. Consideration for development of lactose-free food. In: Journal of Nutrition \& Intermediary Metabolism, 2019, 15, 27-34.

9. Luyt D., Ball H., Makwana N., et al. BSACl guideline for the diagnosis and management of cow's milk allergy. In: Clin Exp Allergy. 2014, 44(5), 642-672. 
10.Lule V.K., Garg S., Tomar S.K., Khedkar D.N., Nalage D.N. Foog intolerance: Lactose intolerance. In: Encyclopedia of Food and Health, 2016, 43-48.

11. Melvin B. H. Lactose Intolerance in Infants, Children, and Adolescents. In: Pediatrics 2006, 118 (3), 12791286.

12. Crittenden, R.G., Bennett, L.E. Cow's milk allergy: a complex disorder. In: Journal of the American College of Nutrition 2005, 24(5), 82S-91S.

13. Misselwitz B., Pohl D., Fruhauf H., Fried M., Vavricka S.R. Fox M. Lactose malabsorption and intolerance: pathogenesis, diagnosis and treatment. In: United European Gastroenterology, 2013, 1:15, 1-9.

14. European Food Safety Authority. Scientific Opinion on Lactose thresholds in lactose intolerance and galactosaemia. In: EFSA J. 2010, 8(9), 1-29.

15. Vandenplas Y., Brueton M., Dupont C., Hill D., Isolauri E., Koletzko S., et al. Guidelines for the diagnosis and management of cow's milk protein allergy in infants. In: Arch Dis Child. 2007, 92(10):902-908.

16. Rangel A. et al. Lactose intolerance and cow's milk protein allergy. In: Food Science and Technology, Campinas, 2016, 36(2), 179-187.

17. Gille D., Walther B., Badertscher R., Bosshart A., Brügger C., Brühlhart M., and Egger L. Detection of lactose in products with low lactose content. In: International Dairy Journal, 2018, 83, 17-19.

18. Suchy F.J., Brannon P.M., Carpenter T.O., et al. National Institutes of Health Consensus Development Conference: lactose intolerance and health. In: Ann Intern Med. 2010, 152(12), 792-796.

19. Rabot $S$ et al. Guidance for substantiating the evidence for beneficial effects of probiotics: impact of probiotics on digestive system metabolism. In: Journal of Nutrition, 2010, 140, 677S-689S.

20. Bailey R.K. et al. Lactose intolerance and health disparities among African Americans and Hispanic Americans: an updated consensus statement. In: Journal of National Medical Association, 2013, 105, 112-127.

21. European Food Safety Authority. Scientific opinion on the substantiation of health claims related to live yoghurt cultures and improved lactose digestion (ID 1143,2976) pursuant to Article 13(1) of Regulation (EC) No 1924/2006. In: EFSA Journal. 2010, 8(10):1763-1781.

22.FAO/WHO. Fats and fatty acids in human nutrition. Report on an expert consultation. In: FAO Food and Nutrition Paper. 2010.

23. Messia M.C., Candigliota T., Marconi E. Assessment of quality and technological characterization of lactosehydrolyzed milk. In: Food Chemistry, 2007, 104(3), 910-917.

24. Iannotti L., Muehlhoff E., Mcmahon D. Review of milk and dairy programs affecting nutrition. In: J. Dev. Effectiveness, 2013, 5(1), 82-115.

25. Tratnik L., Božanić R., Mioković G., Šubarić D. Optimisation of manufacture and quality of cottage cheese, Food Technol. In: Biotechnology, 2001, 39, 43-48.

26. Costa S.L., Rossi N.P., Maldonado R.R. Evaluation of lactose in milk and dairy products. In: International Journal for Innovation Education and Research, 2013, 1, 1-3.

27. Murtaza, M.A., Rehman, S.U., Anjum, F.M., Nawaz, H., Nutritional comparison of cow and buffalo milk Cheddar cheese. In: Pakistan Journal of Nutrition 2008, 7, 509-512.

28.Jana, A.H., Mandal, P.K. Manufacturing and quality of mozzarella cheese: a review. In: International Journal of Dairy Science 2011, 6, 199-226.

29. Otles S., Cagindi O. Kefir: a probiotic dairy-composition, nutritional and therapeutic aspects. In: Pakistan Journal of Nutrition, 2003, 2, 54-59.

30. Usai-Satta P., Scarpa M., Oppia F., Cabras F. Lactose malabsorption and intolerance: What should be the best clinical management? In: World J Gastrointest Pharmacol Ther. 2012, 3(3), 29-33.

31. WGO Handbook on Diet and the Gut, 2016.

32. Kaur G., Kumar V., Goyal A., Tanwar B., Kaur J. Optimization of nutritional beverage developed from radish, sugarcane and herbal extract using response surface methodology. In: Nutritional Food Science, 2018, 48(5) 733-743.

33. Wahlqvist M.L. Lactose nutrition in lactase nonpersisters. In: Asia Pacific Journal Clinical Nutrition 2015, 24, 21-25.

34. Hodges J.K., Cao S., Cladis D.P., Weaver C.M. Lactose intolerance and bone health: The challenge of ensuring adequate calcium intake. In: Nutrients 2019, 11, 1-17.

35. Silanikove N., Leitner G., Merin U., The interrelationships between lactose intolerance and the modern dairy industry: global perspectives in evolutional and historical backgrounds. In: Nutrients, 2015, 7, 7312-7331.

36. Da Silva, Franceline, laguczeski, et. al. Production of naturally "lactose free" fresh cheese". In: Research, Society and Development, 2020, 9(10), e4619108590, (CC BY 4.0), ISSN 2525-3409. 
37. Euromonitor Database. Available online: https://www.euromonitor.com/

38. Dekker P., et al. Lactose-Free Dairy Products: Market Developments, Production, Nutrition and Health Benefits. In: Nutrients 2019, 11, 551, 1-14.

39. Husain Q. $\beta$-Galactosidases and their potential applications: A review, Critical Reviews in Biotechnology. 2010, 30, 41-62.

40. Panesar P. S., Panesar R., Singh R. S., Kennedy J. F., Kumar H. Microbial production, immobilization and applications of $\beta$-D-galactosidase. In: Journal of Chemical Technology and Biotechnology. 2006, 81, 530-543.

41. Carević M.B. et. al. Characterization of $\beta$-galactosidase from lactobacillus acidophilus: stability and kinetic study. In: Advanced technologies, 2017, 6(1) 5-13.

42. Lactose free dairy for special diets. https://www.gea.com/en/stories/lactose-free.jsp

43. Jelen P., Tossavainen O. Low lactose and lactose-free milk and dairy products-prospects, technologies and applications. In: Australian Journal of Dairy Technology, 2003, 89, 514-25.

44. Harju $M$, Kallioinen $H$, Tossavainen $O$. Lactose hydrolysis and other conversions in dairy products: technological aspects. In: International Dairy Journal, 2012, 22(2), 104-109.

45. Technologies for the production of lactose-free products. Available: https://www.valio.ru/valiology/kakproizvoditsya-bezlaktoznoe-moloko/?650 (In Russian)

46. McCain, H.R.; Kaliappan, S.; Drake, M.A. Invited review: Sugar reduction in dairy products. In: J. Dairy Sci. 2018, 101, 8619-8640.

47. Olano A., Corzo N. Lactulose as a food ingredient. In: Journal of the Science of Food and Agriculture, 2009, 89, 1987-1990.

48. Lima T. et al. Manufacture of a fermented dairy product using whey from sheep's milk cheese: an alternative to using the main by-product of sheep's milk cheese production in small farms. In: International Dairy Journal, 2020, 111, 104833.

49. Silanikove N., Leitner G., Merin U. The interrelationships between lactose intolerance and the modern dairy industry: global perspectives in evolutional and historical backgrounds. In: Nutrients. 2015, 7, $7312-31$.

50. Kok C.R., Hutkins R. Yogurt and other fermented foods as sources of health-promoting bacteria. In: Nutr Rev. 2018; 76 (Supplement 1), 4-15.

51. Oak S.J., Jha R. The efects of probiotics in lactose intolerance: a systematic review. In: Crit Rev Food Sci Nutr. 2019, 59, 1675-1683.

52. Levri K.M., Ketvertis K., Deramo M., Merenstein, J.H., D’Amico, F. Do probiotics reduce adult lactose intolerance? A systematic review. In: J Fam Pract. 2005, 54(7), 613-21.

53. Shaukat A., Levitt M.D., Taylor B.C., MacDonald R., Shamliyan T.A., Kane R.L., et al. Systematic review: efective management strategies for lactose intolerance. In: Ann International Medicine. 2010,152(12), 797-803.

54. European Union. Regulation (EU) No 1169/2011 of the European Parliament and of the Council on the provision of food information to consumers, amending Regulations (EC) No 1924/2006 and (EC) No 1925/2006 of the European Parliament and of the Council, and repealing Commission Directive 87/250/EEC, Council Directive 90/496/EEC, Commission Directive 1999/10/EC, Directive 2000/13/EC of the European Parliament and of the Council, Commission Directives 2002/67/EC and 2008/5/EC and Commission Regulation (EC) No 608/2004. OJ 2011, L304, 18-63.

55. European Union. Regulation (EU) No 609/2013 of the European Parliament and of the Council on food intended for infants and young children, food for special medical purposes, and total diet replacement for weight control and repealing Council Directive 92/52/EEC, Commission Directives 96/8/EC, 1999/21/EC, 2006/125/EC and 2006/141/EC, Directive 2009/39/EC of the European Parliament and of the Council and Commission Regulations (EC) No 41/2009 and (EC) No 953/2009. OJ 2013, L181, 35-56.

56. Churakova E. Et al. Accurate analysis of residual lactose. in low-lactose milk: Comparing a variety of analytical techniques. In: International Dairy Journal, 2019, 96, 126-131.

57. Panseri S.; Pavlovic R.; Castrica M.; Nobile M.; Di Cesare F.; Chiesa L.M. Determination of Carbohydrates in Lactose-Free Dairy Products to Support Food Labelling. In: Foods 2021, 10, 1219.

58. Perati P., De Borba B., Rohrer J. Determination of Lactose in Lactose-Free Milk Products by High-Performance AnionExchange Chromatography with Pulsed Amperometric Detection. In: Thermo Fisher Scientific, Application Note AN 248, AN70236_E 10/12S, Sunnyvale, CA, 2012, 1-8.

59. Monti L., Negri S., Meucci A., Stroppa A., Galli A., Contarini G. Lactose, galactose and glucose determination in naturally "lactose free" hard cheese: HPAEC-PAD method validation. In: Food Chem. 2017, 220, $18-24$. 
60. Ohlsson J.A., Johansson M., Hansson H., Abrahamson A., Byberg L., Smedman A., Lindmark-Månsson H., Lundh $\AA$. Lactose, glucose and galactose content in milk, fermented milk and lactose-free milk products. In: International Dairy Journal, 2017, 73, 151-154.

61.Trani A., Gambacorta G., Loizzo P., Cassone A., Fasciano C., Zambrini A.V., Faccia M. Comparison of HPLC-RI, LC/MS-MS and enzymatic assays for the analysis of residual lactose in lactose-free milk. In: Food Chem. 2017, 233, 385-390.

62.Van Scheppingen W.B., van Hilten P.H., Vijverberg M.P., Duchateau A.L. Selective and sensitive determination of lactose in low-lactose dairy products with HPAEC-PAD. In: J. Chromatogr. B 2017, 1060, 395-399.

63. Garballo-Rubio A., Soto-Chinchilla J., Moreno A., Zafra-Gómez A. Determination of residual lactose in lactosefree cow milk by hydrophilic interaction liquid chromatography (HILIC) coupled to tandem mass spectrometry. In: J. Food Compos. Anal. 2018, 66, 39-45.

64. Halbmayr-Jech E., Kittl R., Weinmann P., Schulz C., Kowalik A., Sygmund C., Brunelle S. Determination of Lactose in Lactose Free and Low-Lactose Milk, Milk Products, and Products Containing Dairy Ingredients by the LactoSens ${ }^{\circledR}$ R Amperometry Method: First Action 2020.01. In: J. AOAC Int. 2020, 103, 1534-1546.

65. Mangan D., et al. A novel enzymatic method for the measurement of lactose in lactose-free products. In: Journal of the Science of Food and Agriculture, 2019, 99, 947-956. 